\title{
Nonsegmental Vitiligo and Autoimmune Mechanism
}

\author{
Naoki Oiso, ${ }^{1}$ Tamio Suzuki, ${ }^{2}$ Kazuyoshi Fukai, ${ }^{3}$ Ichiro Katayama, ${ }^{4}$ and Akira Kawada ${ }^{1}$ \\ ${ }^{1}$ Department of Dermatology, Kinki University Faculty of Medicine, 377-2 Ohno-Higashi, Osaka-Sayama, Osaka 589-8511, Japan \\ ${ }^{2}$ Department of Dermatology, Yamagata University School of Medicine, Yamagata 990-9585, Japan \\ ${ }^{3}$ Department of Dermatology, Osaka City University Graduate School of Medicine, Osaka 545-8585, Japan \\ ${ }^{4}$ Department of Dermatology, Osaka University Graduate School of Medicine, Osaka 565-0871, Japan
}

Correspondence should be addressed to Naoki Oiso, naoiso@med.kindai.ac.jp

Received 31 March 2011; Revised 30 May 2011; Accepted 1 June 2011

Academic Editor: Davinder Parsad

Copyright (C) 2011 Naoki Oiso et al. This is an open access article distributed under the Creative Commons Attribution License, which permits unrestricted use, distribution, and reproduction in any medium, provided the original work is properly cited.

\begin{abstract}
Nonsegmental vitiligo is a depigmented skin disorder showing acquired, progressive, and depigmented lesions of the skin, mucosa, and hair. It is believed to be caused mainly by the autoimmune loss of melanocytes from the involved areas. It is frequently associated with other autoimmune diseases, particularly autoimmune thyroid diseases including Hashimoto's thyroiditis and Graves' disease, rheumatoid arthritis, type 1 diabetes, psoriasis, pernicious anemia, systemic lupus erythematosus, Addison's disease, and alopecia areata. This indicates the presence of genetically determined susceptibility to not only vitiligo but also to other autoimmune disorders. Here, we summarize current understanding of autoimmune pathogenesis in non-segmental vitiligo.
\end{abstract}

\section{Nonsegmental Vitiligo}

Nonsegmental vitiligo is acquired depigmented skin lesions mainly caused by autoimmune loss of melanocytes. Genetic and environmental factors are involved in the development. Recent genetic studies identified predisposed genes involving the development of nonsegmental vitiligo [1-5]. Current histopathological studies showed increased infiltration of dendritic cells, Th17 cells [6], and CD8+ cytotoxic T lymphocytes [7-10] in the margin of vitiligo and the reduced number of regulatory $\mathrm{T}$ (Treg) cells in the affected skin $[11,12]$.

\section{Genetics in Nonsegmental Vitiligo}

Genome-wide association studies are applied for identifying the candidate genes in multifactor-associated disorders such as nonsegmental vitiligo [1-5]. In 2007, NALP1 was revealed to be associated with the risk of nonsegmental vitiligo in Caucasians [1]. The subsequent studies in Caucasians identified multiple loci on major-histocompatibility-complex (MHC) class I molecules, MHC class II molecules, PTPN22, LPP, IL2RA, UBASH3A, C1QTNF6, RERE, GZMB, TYR, FOXP1, CCR6, TSLP, XBP1, and FOXP3 [2-4]. Another study in Chinese Han population detected two independent loci within the MHC region and a locus at $6 \mathrm{q} 27$ containing RNASET2, FGFR1OP, and CCR6 [5]. The current candidate genes of nonsegmental vitiligo are summarized in Table 1 [13-91]. These genes are classified into (i) autoantigen, (ii) innate immunity, (iii) innate and acquired immunity, and (iv) other function and miscellaneous. Importantly, nonsegmental vitiligo-susceptible genes are often involved in other autoimmune disorders. Further study is needed to identify additional nonsegmental vitiligo susceptible genes and to elucidate the pathologic mechanism of the genes in nonsegmental vitiligo.

\section{Immunology in Nonsegmental Vitiligo}

Nonsegmental vitiligo can be caused by an immunologically complex mechanism. A variety of melanocytes-expressing proteins have been identified as autoantigens. Cui et al. showed that $24(83 \%)$ of 29 vitiligo patients had autoantibody to melanocytes-associated autoantigen versus 2 (7\%) of 28 healthy controls [92]. Until now, various proteins have been detected as autoantigens including tyrosinase [93-95], tyrosinase-related protein 1 [96-99], tyrosinase-related protein 2 [96, 100], Pmel17 [101, 102], melanin-concentrating hormone receptor 1 [103], tyrosine hydroxylase [104], and 


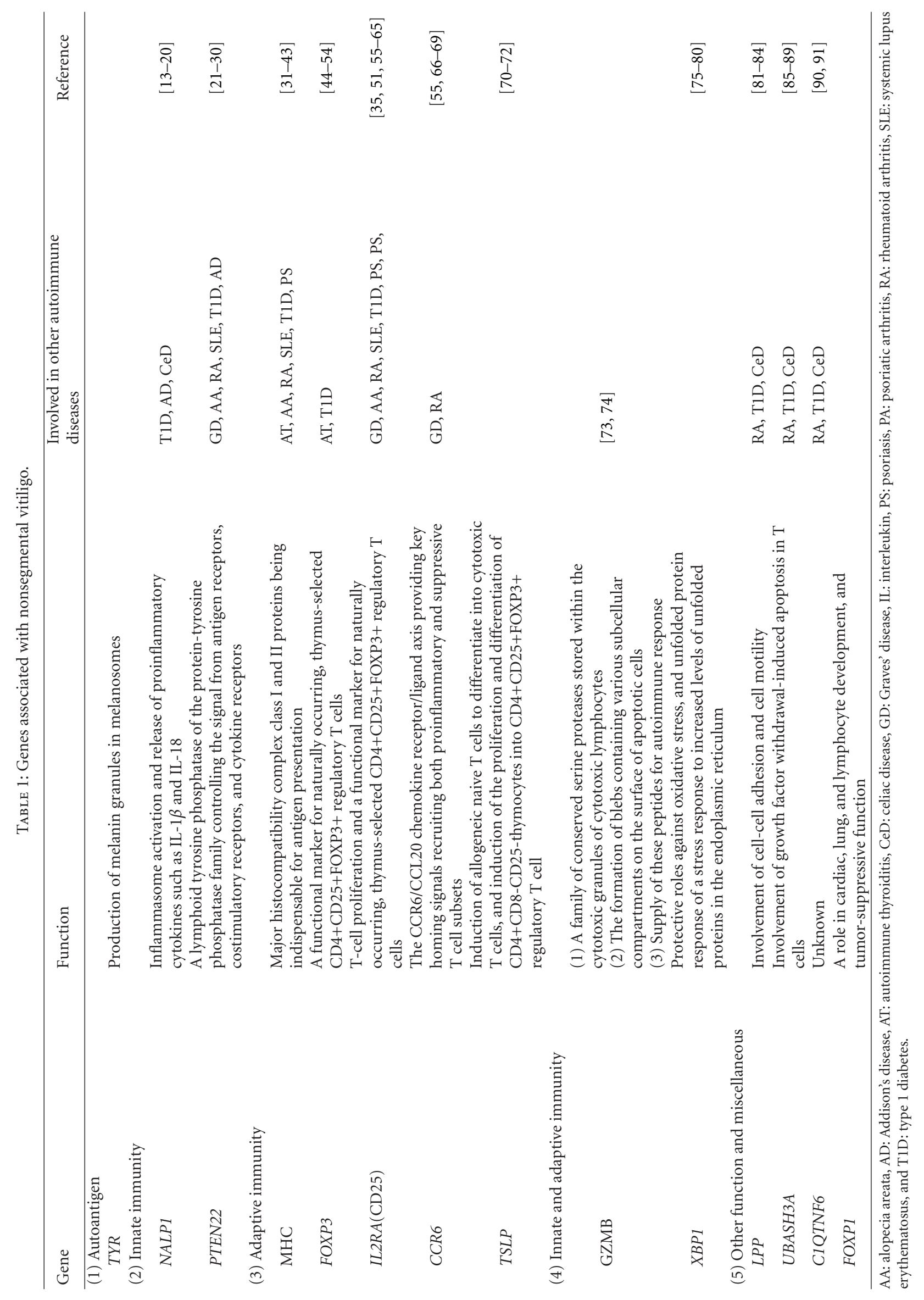


lamin A [99]. Antityrosine hydroxylase autoantibody was more frequent in active vitiligo patients [104], suggesting potency as an activity marker. Using radioimmunoassay, Waterman et al. found positive antibody reactivity to gamma-enolase (8\%), alpha-enolase (9\%), heat-shock protein $90(13 \%)$, osteopontin (4\%), ubiquitin-conjugating enzyme (15\%), translation-initiation factor $2(6 \%)$, and Rab38 (guanosine-5' -triphosphate- (GTP-) binding protein) $(15 \%)$ in nonsegmental vitiligo patient sera [105]. Melanocyte-specific antibodies might induce apoptosis of melanocytes [106]. Ruiz-Argüelles et al. reported that serum immunoglobulin $\mathrm{G}$ antibodies from vitiligo patients were able to penetrate cultured melanocytes in vitro and trigger apoptosis [106]. However, further investigations are required to elucidate the pathogenetic function of autoantibodies [107].

Histopathological studies demonstrated the increased dendritic cells [6], Th17 cells [6, 108], and CD8+ cytotoxic T lymphocytes [7-10] and the decreased naturally occurring CD4+CD25+FOXP3+ Treg cells $[11,12]$ at the margin of vitiligo lesions. The infiltrating cytotoxic $\mathrm{CD} 8+\mathrm{T}$ cells recognize melanocyte-associated autoantigens and enable to locate at dermal-epidermal junctions [109]. The paucity of Treg in vitiligo skin causes perpetual antimelanocyte reactivity in nonsegmental vitiligo $[110,111]$. The role of Treg and Th17 cells should be elucidated in order to understand the balance between the occurrence and suppression of the autoimmune reaction.

The activation of inflammasome constructed by NODlike receptors such as NALP-1 overproduces proinflammatory cytokines of IL- $1 \beta$ and IL-18, inducing apoptosis [112]. Interestingly, Wang et al. showed the increased IL- $1 \beta$ level in the vitiligo lesion and the expression of NALP-1 in the activated epidermal Langerhans cells and dermal dendritic cells [6]. As IL- $1 \beta$ is the essential cytokine to develop Th17 cells [6], IL-1 $\beta$ produced by activated inflammasome may involve the development of nonsegmental vitiligo.

\section{Conclusion}

Considerable progress is being made towards understanding the pathogenesis of nonsegmental vitiligo. Although a number of genes have been implicated by well-designed genomewide association studies, we do not have good genotypephenotype correlations. In the future, we can anticipate further advancement regarding specific interactions between disease-susceptible genes and gene-environment interactions.

\section{Conflict of Interests}

The authors declared that there is no conflict of interests.

\section{Acknowledgments}

This work was supported by Grant-In-Aid no. 21591449 from the Ministry of Education, Science and Culture of Japan (to N. Oiso) and by a Grant-In-Aid from Health Sciences
Research grants from the Ministry of Health, Welfare and Labor of Japan.

\section{References}

[1] Y. Jin, C. M. Mailloux, K. Gowan et al., "NALP1 in vitiligoassociated multiple autoimmune disease," New England Journal of Medicine, vol. 356, no. 12, pp. 1216-1225, 2007.

[2] Y. Jin, S. A. Birlea, P. R. Fain et al., "Variant of TYR and autoimmunity susceptibility loci in generalized vitiligo," New England Journal of Medicine, vol. 362, no. 18, pp. 1686-1697, 2010.

[3] Y. Jin, S. A. Birlea, P. R. Fain et al., "Common variants in FOXP1 are associated with generalized vitiligo," Nature Genetics, vol. 42, no. 7, pp. 576-578, 2010.

[4] S. A. Birlea, Y. Jin, D. C. Bennett et al., "Comprehensive association analysis of candidate genes for generalized vitiligo supports XBP1, FOXP3, and TSLP," Journal of Investigative Dermatology, vol. 131, no. 6, pp. 371-381, 2010.

[5] C. Quan, Y. Q. Ren, L. H. Xiang et al., "Genome-wide association study for vitiligo identifies susceptibility loci at 6q27 and the MHC," Nature Genetics, vol. 42, no. 7, pp. 614$618,2010$.

[6] C. Q. Wang, A. E. Cruz-Inigo, J. Fuentes-Duculan et al., "Th17 cells and activated dendritic cells are increased in vitiligo lesions," PLoS ONE, vol. 6, no. 4, article e18907, 2011.

[7] R. K. Gregg, L. Nichols, Y. Chen, B. Lu, and V. H. Engelhard, "Mechanisms of spatial and temporal development of autoimmune vitiligo in tyrosinase-specific TCR transgenic mice," Journal of Immunology, vol. 184, no. 4, pp. 1909-1917, 2010.

[8] K. I. Yamanaka, M. Kakeda, H. Kitagawa et al., "1,24Dihydroxyvitamin $\mathrm{D}_{3}$ (tacalcitol) prevents skin T-cell infiltration," British Journal of Dermatology, vol. 162, no. 6, pp. 1206-1215, 2010.

[9] J. G. Van Den Boorn, D. Konijnenberg, T. A. Dellemijn et al., "Autoimmune destruction of skin melanocytes by perilesional T cells from vitiligo patients," Journal of Investigative Dermatology, vol. 129, no. 9, pp. 2220-2232, 2009.

[10] A. Wańkowicz-Kalińska, R. M. Van den Wijngaard, B. J. Tigges et al., "Immunopolarization of CD4+ and CD8+ T cells to type-1-like is associated with melanocyte loss in human vitiligo," Laboratory Investigation, vol. 83, no. 5, pp. 683-695, 2003.

[11] P. Y. Basak, A. K. Adiloglu, A. M. Ceyhan, T. Tas, and V. B. Akkaya, "The role of helper and regulatory T cells in the pathogenesis of vitiligo," Journal of the American Academy of Dermatology, vol. 60, no. 2, pp. 256-260, 2009.

[12] J. Klarquist, C. J. Denman, C. Hernandez et al., "Reduced skin homing by functional Treg in vitiligo," Pigment Cell and Melanoma Research, vol. 23, no. 2, pp. 276-286, 2010.

[13] A. Pontillo, A. Vendramin, E. Catamo, A. Fabris, and S. Crovella, "The missense variation Q705K in CIAS1/ NALP3/NLRP3 gene and an NLRP1 haplotype are associated with celiac disease," American Journal of Gastroenterology, vol. 106, no. 3, pp. 539-544, 2011.

[14] S. M. Gregory, B. K. Davis, J. A. West et al., "Discovery of a viral NLR homolog that inhibits the inflammasome," Science, vol. 331, no. 6015, pp. 330-334, 2011.

[15] M. Zurawek, M. Fichna, D. Januszkiewicz-Lewandowska, M. Gryczyńska, P. Fichna, and J. Nowak, "A coding variant in NLRP1 is associated with autoimmune Addison's disease," Human Immunology, vol. 71, no. 5, pp. 530-534, 2010. 
[16] P. J. Shaw, M. Lamkanfi, and T. D. Kanneganti, "NODlike receptor (NLR) signaling beyond the inflammasome," European Journal of Immunology, vol. 40, no. 3, pp. 624-627, 2010.

[17] N. F. Magitta, A. S. Bøe Wolff, S. Johansson et al., "A coding polymorphism in NALP1 confers risk for autoimmune Addison's disease and type 1 diabetes," Genes and Immunity, vol. 10, no. 2, pp. 120-124, 2009.

[18] J. P. Ting, R. C. Lovering, E. S. Alnemri et al., "The NLR gene family: a standard nomenclature," Immunity, vol. 28, no. 3, pp. 285-287, 2008.

[19] T. D. Kanneganti, M. Lamkanfi, and G. Núñez, "Intracellular NOD-like receptors in host defense and disease," Immunity, vol. 27, no. 4, pp. 549-559, 2007.

[20] S. Mariathasan, D. S. Weiss, K. Newton et al., "Cryopyrin activates the inflammasome in response to toxins and ATP," Nature, vol. 440, no. 7081, pp. 228-232, 2006.

[21] M. Roycroft, M. Fichna, D. McDonald et al., "The tryptophan 620 allele of the lymphoid tyrosine phosphatase (PTPN22) gene predisposes to autoimmune Addison's disease," Clinical Endocrinology, vol. 70, no. 3, pp. 358-362, 2009.

[22] T. Vang, A. V. Miletic, Y. Arimura, L. Tautz, R. C. Rickert, and T. Mustelin, "Protein tyrosine phosphatases in autoimmunity, Annual Review of Immunology, vol. 26, pp. 29-55, 2008.

[23] R. C. Betz, K. König, A. Flaquer et al., "The R620W polymorphism in PTPN22 confers general susceptibility for the development of alopecia areata," British Journal of Dermatology, vol. 158, no. 2, pp. 389-391, 2008.

[24] E. H. Kemp, A. J. G. McDonagh, D. A. Wengraf et al., "The non-synonymous C1858T substitution in the PTPN22 gene is associated with susceptibility to the severe forms of alopecia areata," Human Immunology, vol. 67, no. 7, pp. 535539, 2006.

[25] T. Vang, M. Congia, M. D. Macis et al., "Autoimmuneassociated lymphoid tyrosine phosphatase is a gain-offunction variant," Nature Genetics, vol. 37, no. 12, pp. 13171319, 2005.

[26] G. Orozco, E. Sánchez, M. A. González-Gay et al., “Association of a functional single-nucleotide polymorphism of PTPN22, encoding lymphoid protein phosphatase, with rheumatoid arthritis and systemic lupus erythematosus," Arthritis and Rheumatism, vol. 52, no. 1, pp. 219-224, 2005.

[27] N. Bottini, L. Musumeci, A. Alonso et al., "A functional variant of lymphoid tyrosine phosphatase is associated with type I diabetes," Nature Genetics, vol. 36, no. 4, pp. 337-338, 2004.

[28] A. B. Begovich, V. E. H. Carlton, L. A. Honigberg et al., "A missense single-nucleotide polymorphism in a gene encoding a protein tyrosine phosphatase (PTPN22) is associated with rheumatoid arthritis," American Journal of Human Genetics, vol. 75, no. 2, pp. 330-337, 2004.

[29] C. Kyogoku, C. D. Langefeld, W. A. Ortmann et al., "Genetic association of the R620W polymorphism of protein tyrosine phosphatase PTPN22 with human SLE," American Journal of Human Genetics, vol. 75, no. 3, pp. 504-507, 2004.

[30] M. R. Velaga, V. Wilson, C. E. Jennings et al., "The codon 620 tryptophan allele of the lymphoid tyrosine phosphatase (LYP) gene is a major determinant of Graves' disease," Journal of Clinical Endocrinology and Metabolism, vol. 89, no. 11, pp. 5862-5865, 2004.

[31] P. A. Van Der Merwe and O. Dushek, "Mechanisms for T cell receptor triggering," Nature Reviews Immunology, vol. 11, no. 1, pp. 47-55, 2011.
[32] K. W. Wucherpfennig and D. Sethi, "T cell receptor recognition of self and foreign antigens in the induction of autoimmunity," Seminars in Immunology, vol. 23, no. 2, pp. 84-91, 2011.

[33] L. Handunnetthi, S. V. Ramagopalan, G. C. Ebers, and J. C. Knight, "Regulation of major histocompatibility complex class II gene expression, genetic variation and disease," Genes and Immunity, vol. 11, no. 2, pp. 99-112, 2010.

[34] F. Menconi, R. Osman, M. C. Monti, D. A. Greenberg, E. S. Concepcion, and Y. Tomer, "Shared molecular amino acid signature in the HLA-DR peptide binding pocket predisposes to both autoimmune diabetes and thyroiditis," Proceedings of the National Academy of Sciences of the United States of America, vol. 107, no. 39, pp. 16899-16903, 2010.

[35] L. Petukhova, M. Duvic, M. Hordinsky et al., "Genome-wide association study in alopecia areata implicates both innate and adaptive immunity," Nature, vol. 466, no. 7302, pp. 113$117,2010$.

[36] A. A. Zeitlin, M. J. Simmonds, and S. C. Gough, "Genetic developments in autoimmune thyroid disease: an evolutionary process," Clinical Endocrinology, vol. 68, no. 5, pp. 671682, 2008.

[37] N. Barahmani, M. De Andrade, J. P. Slusser et al., "Human leukocyte antigen class II alleles are associated with risk of alopecia areata," Journal of Investigative Dermatology, vol. 128, no. 1, pp. 240-243, 2008.

[38] N. Barahmani, M. De Andrade, J. P. Slusser, Q. Zhang, and M. Duvic, "Major histocompatibility complex class I chainrelated gene a polymorphisms and extended haplotypes are associated with familial alopecia areata," Journal of Investigative Dermatology, vol. 126, no. 1, pp. 74-78, 2006.

[39] N. Lench, M. M. Iles, I. Mackay et al., "Single-point haplotype scores telomeric to human leukocyte antigen-C give a high susceptibility major histocompatability complex haplotype for psoriasis in a Caucasian population," Journal of Investigative Dermatology, vol. 124, no. 3, pp. 545-552, 2005.

[40] J. L. Newton, S. M. J. Harney, B. P. Wordsworth, and M. A. Brown, "A review of the MHC genetics of rheumatoid arthritis," Genes and Immunity, vol. 5, no. 3, pp. 151-157, 2004.

[41] C. E. Larsen and C. A. Alper, "The genetics of HLA-associated disease," Current Opinion in Immunology, vol. 16, no. 5, pp. 660-667, 2004.

[42] R. P. Nair, P. Stuart, T. Henseler et al., "Localization of psoriasis-susceptibility locus PSORS1 to a $60-\mathrm{kb}$ interval telomeric to HLA-C," American Journal of Human Genetics, vol. 66, no. 6, pp. 1833-1844, 2000.

[43] C. G. Drake and B. L. Kotzin, "Genetic and immunological mechanisms in the pathogenesis of systemic lupus erythematosus," Current Opinion in Immunology, vol. 4, no. 6, pp. 733-740, 1992.

[44] J. H. Buckner, "Mechanisms of impaired regulation by CD4+ CD25+ FOXP3+ regulatory T cells in human autoimmune diseases," Nature Reviews Immunology, vol. 10, no. 12, pp. 849-859, 2010.

[45] N. Oiso, "Regulatory T cells in atopic dermatitis," Recent Patents on Inflammation and Allergy Drug Discovery, vol. 4, no. 3, pp. 244-248, 2010.

[46] N. Inoue, M. Watanabe, M. Morita et al., "Association of functional polymorphisms related to the transcriptional level of FOXP3 with prognosis of autoimmune thyroid diseases," Clinical and Experimental Immunology, vol. 162, no. 3, pp. 402-406, 2010.

[47] E. D’Hennezel, M. Ben-Shoshan, H. D. Ochs et al., "FOXP3 forkhead domain mutation and regulatory $\mathrm{T}$ cells in the IPEX 
syndrome," New England Journal of Medicine, vol. 361, no. 17, pp. 1710-1713, 2009.

[48] M. A. Curotto de Lafaille and J. J. Lafaille, "Natural and adaptive foxp3+ regulatory $\mathrm{T}$ cells: more of the same or a division of labor?” Immunity, vol. 30, no. 5, pp. 626-635, 2009.

[49] M. J. B. Villano, A. K. Huber, D. A. Greenberg, B. K. Golden, E. Concepcion, and Y. Tomer, "Autoimmune thyroiditis and diabetes: dissecting the joint genetic susceptibility in a large cohort of multiplex families," Journal of Clinical Endocrinology and Metabolism, vol. 94, no. 4, pp. 1458-1466, 2009.

[50] Z. Zhou, X. Song, B. Li, and M. I. Greene, "FOXP3 and its partners: structural and biochemical insights into the regulation of FOXP3 activity," Immunologic Research, vol. 42, no. 1-3, pp. 19-28, 2008.

[51] Y. Liu, C. Helms, W. Liao et al., "A genome-wide association study of psoriasis and psoriatic arthritis identifies new disease loci," PLoS Genetics, vol. 4, no. 3, Article ID e1000041, 2008.

[52] M. Akdis, K. Blaser, and C. A. Akdis, "T regulatory cells in allergy: novel concepts in the pathogenesis, prevention, and treatment of allergic diseases," Journal of Allergy and Clinical Immunology, vol. 116, no. 5, pp. 961-969, 2005.

[53] R. S. Wildin, F. Ramsdell, J. Peake et al., "X-linked neonatal diabetes mellitus, enteropathy and endocrinopathy syndrome is the human equivalent of mouse scurfy," Nature Genetics, vol. 27, no. 1, pp. 18-20, 2001.

[54] C. L. Bennett, J. Christie, F. Ramsdell et al., "The immune dysregulation, polyendocrinopathy, enteropathy, X-linked syndrome (IPEX) is caused by mutations of FOXP3," Nature Genetics, vol. 27, no. 1, pp. 20-21, 2001.

[55] E. A. Stahl, S. Raychaudhuri, E. F. Remmers et al., "Genomewide association study meta-analysis identifies seven new rheumatoid arthritis risk loci," Nature Genetics, vol. 42, no. 6, pp. 508-514, 2010

[56] J. C. Crispín and G. C. Tsokos, "Transcriptional regulation of IL-2 in health and autoimmunity," Autoimmunity Reviews, vol. 8, no. 3, pp. 190-195, 2009.

[57] E. J. Carr, M. R. Clatworthy, C. E. Lowe et al., "Contrasting genetic association of IL2RA with SLE and ANCA-associated vasculitis," BMC Medical Genetics, vol. 10, article 22, 2009.

[58] C. E. Lowe, J. D. Cooper, T. Brusko et al., "Large-scale genetic fine mapping and genotype-phenotype associations implicate polymorphism in the IL2RA region in type 1 diabetes," Nature Genetics, vol. 39, no. 9, pp. 1074-1082, 2007.

[59] M. F. Bachmann and A. Oxenius, "Interleukin 2: from immunostimulation to immunoregulation and back again," EMBO Reports, vol. 8, no. 12, pp. 1142-1148, 2007.

[60] A. Laurence, C. M. Tato, T. S. Davidson et al., "Interleukin2 Signaling via STAT5 Constrains T Helper 17 Cell Generation," Immunity, vol. 26, no. 3, pp. 371-381, 2007.

[61] O. J. Brand, C. E. Lowe, J. M. Heward et al., "Association of the interleukin-2 receptor alpha (IL-2R $\alpha) / C D 25$ gene region with Graves' disease using a multilocus test and tag SNPs," Clinical Endocrinology, vol. 66, no. 4, pp. 508-512, 2007.

[62] A. Vella, J. D. Cooper, C. E. Lowe et al., "Localization of a type 1 diabetes locus in the IL2RA/CD25 region by use of tag single-nucleotide polymorphisms," American Journal of Human Genetics, vol. 76, no. 5, pp. 773-779, 2005.

[63] M. F. Bachmann and M. Kopf, "Balancing protective immunity and immunopathology," Current Opinion in Immunology, vol. 14, no. 4, pp. 413-419, 2002.

[64] B. Kneitz, T. Herrmann, S. Yonehara, and A. Schimpl, "Normal clonal expansion but impaired Fas-mediated cell death and anergy induction in interleukin-2-deficient mice," European Journal of Immunology, vol. 25, no. 9, pp. 25722577, 1995.

[65] M. J. Lenardo, "Interleukin-2 programs mouse $\alpha \beta$ T lymphocytes for apoptosis," Nature, vol. 353, no. 6347, pp. 858-861, 1991.

[66] I. Comerford, M. Bunting, K. Fenix et al., "An immune paradox: how can the same chemokine axis regulate both immune tolerance and activation?: CCR6/CCL20: a chemokine axis balancing immunological tolerance and inflammation in autoimmune disease," BioEssays, vol. 32, no. 12, pp. 10671076, 2010.

[67] Y. Kochi, Y. Okada, A. Suzuki et al., "A regulatory variant in CCR6 is associated with rheumatoid arthritis susceptibility," Nature Genetics, vol. 42, no. 6, pp. 515-519, 2010.

[68] K. S. Voo, Y. H. Wang, F. R. Santori et al., "Identification of IL-17-producing FOXP3+ regulatory T cells in humans," Proceedings of the National Academy of Sciences of the United States of America, vol. 106, no. 12, pp. 4793-4798, 2009.

[69] T. Yamazaki, X. O. Yang, Y. Chung et al., "CCR6 regulates the migration of inflammatory and regulatory T cells," Journal of Immunology, vol. 181, no. 12, pp. 8391-8401, 2008.

[70] S. Hanabuchi, T. Ito, W. R. Park et al., "Thymic stromal lymphopoietin-activated plasmacytoid dendritic cells induce the generation of FOXP3+ regulatory $\mathrm{T}$ cells in human thymus," Journal of Immunology, vol. 184, no. 6, pp. 29993007, 2010.

[71] J. Wang and F. Xing, "Human TSLP-educated DCs," Cellular \& Molecular Immunology, vol. 5, no. 2, pp. 99-106, 2008.

[72] N. Watanabe, Y. H. Wang, H. K. Lee et al., "Hassall's corpuscles instruct dendritic cells to induce CD4 +CD25+ regulatory T cells in human thymus," Nature, vol. 436, no. 7054, pp. 1181-1185, 2005.

[73] W. A. Boivin, D. M. Cooper, P. R. Hiebert, and D. J. Granville, "Intracellular versus extracellular granzyme B in immunity and disease: challenging the dogma," Laboratory Investigation, vol. 89, no. 11, pp. 1195-1220, 2009.

[74] L. A. Casciola-Rosen, G. Anhalt, and A. Rosen, "Autoantigens targeted in systemic lupus erythematosus are clustered in two populations of surface structures on apoptotic keratinocytes," Journal of Experimental Medicine, vol. 179, no. 4, pp. 1317-1330, 1994.

[75] A. Celli, D. S. MacKenzie, D. S. Crumrine et al., "Endoplasmic reticulum $\mathrm{Ca} 2+$ depletion activates XBP1 and controls terminal differentiation in keratinocytes and epidermis," British Journal of Dermatology, vol. 164, no. 1, pp. 16-25, 2011.

[76] M. Hirai, N. Kadowaki, T. Kitawaki et al., "Bortezomib suppresses function and survival of plasmacytoid dendritic cells by targeting intracellular trafficking of Toll-like receptors and endoplasmic reticulum homeostasis," Blood, vol. 117, no. 2, pp. 500-509, 2011.

[77] K. Y. Tsang, D. Chan, J. F. Bateman, and K. S. E. Cheah, "In vivo cellular adaptation to ER stress: survival strategies with double-edged consequences," Journal of Cell Science, vol. 123, no. 13, pp. 2145-2154, 2010.

[78] F. Martinon, X. Chen, A. H. Lee, and L. H. Glimcher, "TLR activation of the transcription factor XBP1 regulates innate immune responses in macrophages," Nature Immunology, vol. 11, no. 5, pp. 411-418, 2010.

[79] P. Manga, S. Bis, K. Knoll, B. Perez, and S. J. Orlow, "The unfolded protein response in melanocytes: activation in response to chemical stressors of the endoplasmic reticulum and tyrosinase misfolding," Pigment Cell and Melanoma Research, vol. 23, no. 5, pp. 627-634, 2010. 
[80] Y. Liu, M. Adachi, S. Zhao et al., "Preventing oxidative stress: a new role for XBP1," Cell Death and Differentiation, vol. 16, no. 6, pp. 847-857, 2009.

[81] T. G. Grunewald, S. M. Pasedag, and E. Butt, "Cell adhesion and transcriptional activity-defining the role of the novel protooncogene LPP," Translational Oncology, vol. 2, no. 3, pp. 107-116, 2009.

[82] D. J. Smyth, V. Plagnol, N. M. Walker et al., "Shared and distinct genetic variants in type 1 diabetes and celiac disease," New England Journal of Medicine, vol. 359, no. 26, pp. 27672777, 2008.

[83] M. J. Coenen, G. Trynka, S. Heskamp et al., "Common and different genetic background for rheumatoid arthritis and coeliac disease," Human Molecular Genetics, vol. 18, no. 21, pp. 4195-4203, 2009.

[84] A. Hinks, P. Martin, E. Flynn et al., "Investigation of type 1 diabetes and coeliac disease susceptibility loci for association with juvenile idiopathic arthritis," Annals of the Rheumatic Diseases, vol. 69, no. 12, pp. 2169-2172, 2010.

[85] X. Chen, L. Ren, S. Kim et al., "Determination of the substrate specificity of protein-tyrosine phosphatase TULA2 and identification of Syk as a TULA-2 substrate," Journal of Biological Chemistry, vol. 285, no. 41, pp. 31268-31276, 2010.

[86] A. Y. Tsygankov, "TULA-family proteins: an odd couple," Cellular and Molecular Life Sciences, vol. 66, no. 17, pp. 29492952, 2009.

[87] A. Zhernakova, E. A. Stahl, G. Trynka et al., "Meta-analysis of genome-wide association studies in celiac disease and rheumatoid arthritis identifies fourteen non-HLA shared loci," PLoS Genetics, vol. 7, no. 2, Article ID e1002004, 2011.

[88] P. Concannon, S. Onengut-Gumuscu, J. A. Todd et al., "A human type 1 diabetes susceptibility locus maps to chromosome 21q22.3," Diabetes, vol. 57, no. 10, pp. 28582861, 2008.

[89] S. F. Grant, H. Q. Qu, J. P. Bradfield et al., "Follow-Up analysis of genome-wide association data identifies novel loci for type 1 diabetes," Diabetes, vol. 58, no. 1, pp. 290-295, 2009.

[90] S. Eyre, A. Hinks, J. Bowes et al., "Overlapping genetic susceptibility variants between three autoimmune disorders: rheumatoid arthritis, type 1 diabetes and coeliac disease," Arthritis Research \& Therapy, vol. 12, no. 5, p. R175, 2010.

[91] J. D. Cooper, D. J. Smyth, A. M. Smiles et al., "Meta-analysis of genome-wide association study data identifies additional type 1 diabetes risk loci," Nature Genetics, vol. 40, no. 12, pp. 1399-1401, 2008.

[92] J. Cui, Y. Arita, and J. C. Bystryn, "Characterization of vitiligo antigens," Pigment Cell Research, vol. 8, no. 1, pp. 53-59, 1995.

[93] Y. H. Song, E. Connor, Y. Li, B. Zorovich, P. Balducci, and N. Maclaren, "The role of tyrosinase in autoimmune vitiligo," Lancet, vol. 344, no. 8929, pp. 1049-1052, 1994.

[94] E. Baharav, O. Merimski, Y. Shoenfeld et al., "Tyrosinase as an autoantigen in patients with vitiligo," Clinical and Experimental Immunology, vol. 105, no. 1, pp. 84-88, 1996.

[95] E. H. Kemp, D. J. Gawkrodger, S. MacNeil, P. F. Watson, and A. P. Weetman, "Detection of tyrosinase autoantibodies in patients with vitiligo using 35S-labeled recombinant human tyrosinase in a radioimmunoassay," Journal of Investigative Dermatology, vol. 109, no. 1, pp. 69-73, 1997.

[96] H. E. Kemp, E. A. Waterman, D. J. Gawkrodger, P. F. Watson, and A. P. Weetman, "Identification of epitopes on tyrosinase which are recognized by autoantibodies from patients with vitiligo," Journal of Investigative Dermatology, vol. 113, no. 2, pp. 267-271, 1999.

[97] E. H. Kemp, E. A. Waterman, D. J. Gawkrodger, P. F. Watson, and A. P. Weetman, "Autoantibodies to tyrosinaserelated protein-1 detected in the sera of vitiligo patients using a quantitative radiobinding assay," British Journal of Dermatology, vol. 139, no. 5, pp. 798-805, 1998.

[98] K. Jimbow, H. Chen, J. S. Park, and P. D. Thomas, "Increased sensitivity of melanocytes to oxidative stress and abnormal expression of tyrosinase-related protein in vitiligo," British Journal of Dermatology, vol. 144, no. 1, pp. 55-65, 2001.

[99] Q. Li, Y. Lv, C. Li et al., "Vitiligo autoantigen VIT75 is identified as lamin A in vitiligo by serological proteome analysis based on mass spectrometry," Journal of Investigative Dermatology, vol. 131, no. 3, pp. 727-734, 2010.

[100] E. H. Kemp, D. J. Gawkrodger, P. F. Watson, and A. P. Weetman, "Immunoprecipitation of melanogenic enzyme autoantigens with vitiligo sera: evidence for cross-reactive autoantibodies to tyrosinase and tyrosinase-related protein2 (TRP-2)," Clinical and Experimental Immunology, vol. 109, no. 3, pp. 495-500, 1997.

[101] E. H. Kemp, D. J. Gawkrodger, P. F. Watson, and A. P. Weetman, "Autoantibodies to human melanocyte-specific protein Pmell7 in the sera of vitiligo patients: a sensitive and quantitative radioimmunoassay (RIA)," Clinical and Experimental Immunology, vol. 114, no. 3, pp. 333-338, 1998.

[102] E. H. Kemp, E. A. Waterman, D. J. Gawkrodger, P. F. Watson, and A. P. Weetman, "Molecular mapping of epitopes on melanocyte-specific protein Pmel17 which are recognized by autoantibodies in patients with vitiligo," Clinical and Experimental Immunology, vol. 124, no. 3, pp. 509-515, 2001.

[103] N. G. Gavalas, R. V. Gottumukkala, D. J. Gawkrodger, P. F. Watson, A. P. Weetman, and E. H. Kemp, "Mapping of melanin-concentrating hormone receptor $1 \mathrm{~B}$ cell epitopes predicts two major binding sites for vitiligo patient autoantibodies," Experimental Dermatology, vol. 18, no. 5, pp. 454463, 2009.

[104] E. H. Kemp, S. Emhemad, S. Akhtar, P. F. Watson, D. J. Gawkrodger, and A. P. Weetman, "Autoantibodies against tyrosine hydroxylase in patients with non-segmental (generalised) vitiligo," Experimental Dermatology, vol. 20, no. 1, pp. 35-40, 2011.

[105] E. A. Waterman, D. J. Gawkrodger, P. F. Watson, A. P. Weetman, and E. H. Kemp, "Autoantigens in vitiligo identified by the serological selection of a phage-displayed melanocyte cDNA expression library," Journal of Investigative Dermatology, vol. 130, no. 1, pp. 230-240, 2010.

[106] A. Ruiz-Argüelles, G. J. Brito, P. Reyes-Izquierdo, B. PérezRomano, and S. Sánchez-Sosa, "Apoptosis of melanocytes in vitiligo results from antibody penetration," Journal of Autoimmunity, vol. 29, no. 4, pp. 281-286, 2007.

[107] B. Palermo, S. Garbelli, S. Mantovani et al., "Qualitative difference between the cytotoxic $\mathrm{T}$ lymphocyte responses to melanocyte antigens in melanoma and vitiligo," European Journal of Immunology, vol. 35, no. 11, pp. 3153-3162, 2005.

[108] D. A. Bassiouny and O. Shaker, "Role of interleukin-17 in the pathogenesis of vitiligo," Clinical and Experimental Dermatology, vol. 36, no. 3, pp. 292-297, 2011.

[109] K. Oyarbide-Valencia, J. G. van den Boorn, C. J. Denman et al., "Therapeutic implications of autoimmune vitiligo $\mathrm{T}$ cells," Autoimmunity Reviews, vol. 5, no. 7, pp. 486-492, 2006. 
[110] L. P. Li, J. C. Lampert, X. Chen et al., "Transgenic mice with a diverse human T cell antigen receptor repertoire," Nature Medicine, vol. 16, no. 9, pp. 1029-1034, 2010.

[111] J. Klarquist, C. J. Denman, C. Hernandez et al., "Reduced skin homing by functional Treg in vitiligo," Pigment Cell and Melanoma Research, vol. 23, no. 2, pp. 276-286, 2010.

[112] M. Wittmann, A. Macdonald, and J. Renne, "IL-18 and skin inflammation," Autoimmunity Reviews, vol. 9, no. 1, pp. 4548, 2009. 


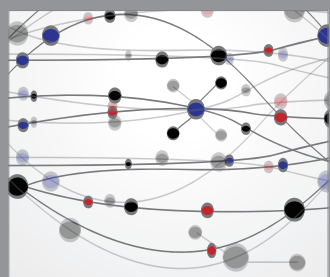

The Scientific World Journal
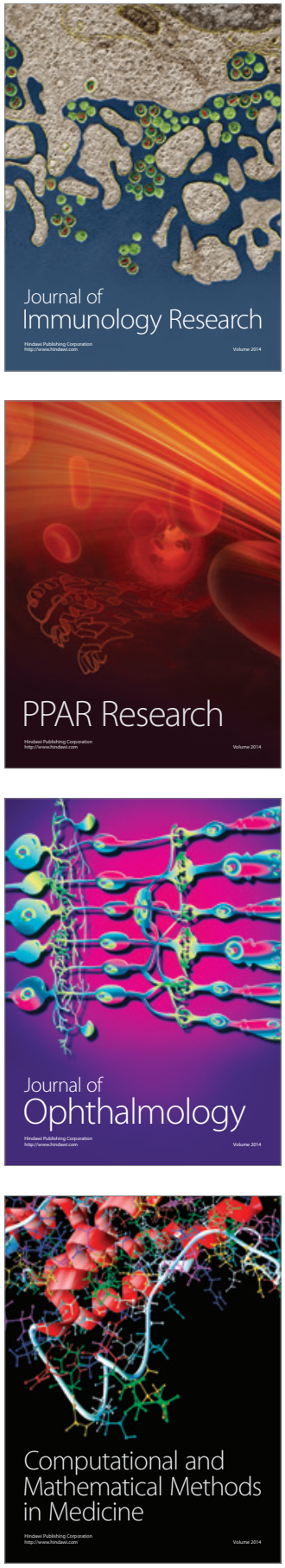

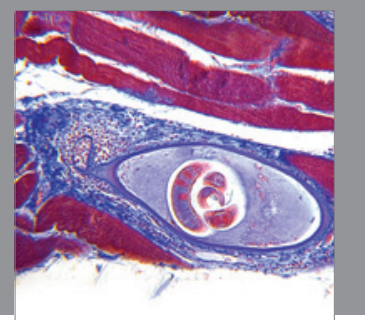

Gastroenterology

Research and Practice
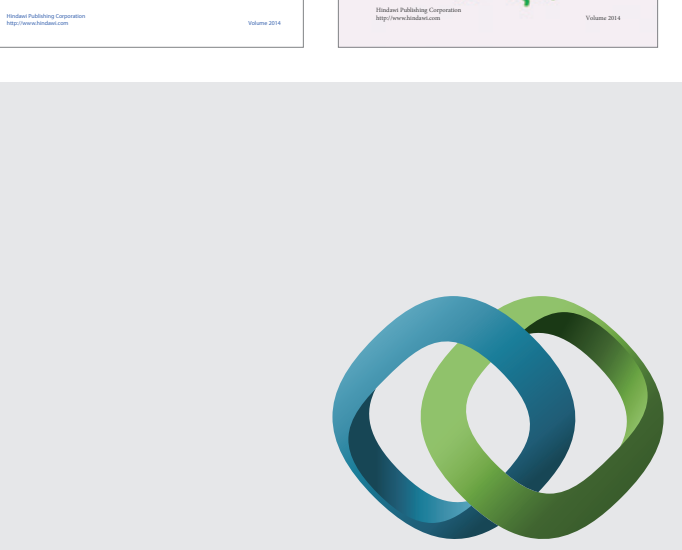

\section{Hindawi}

Submit your manuscripts at

http://www.hindawi.com
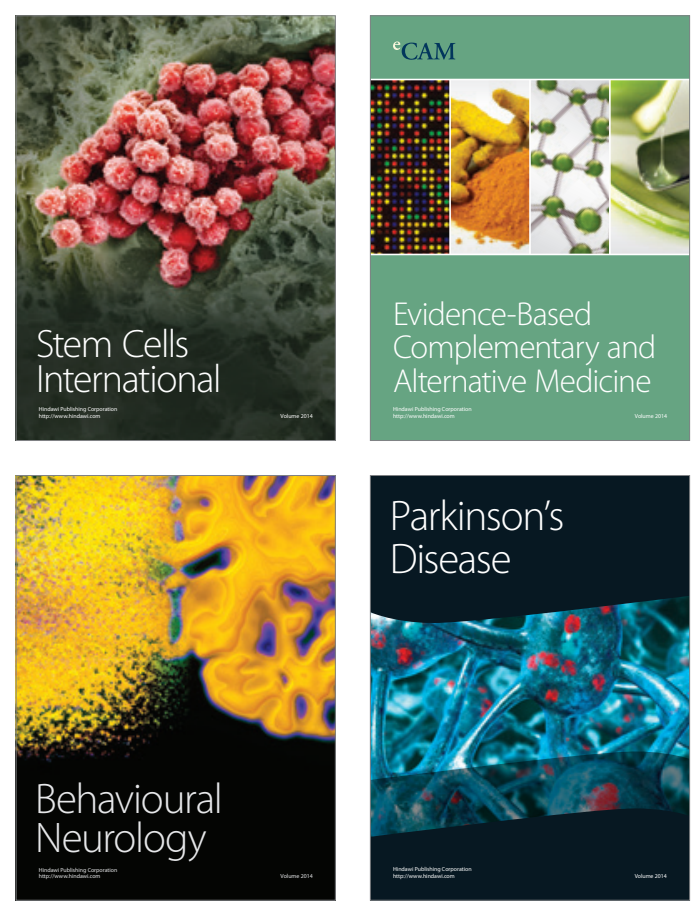

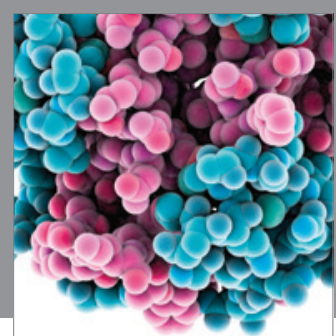

Journal of
Diabetes Research

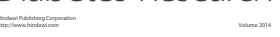

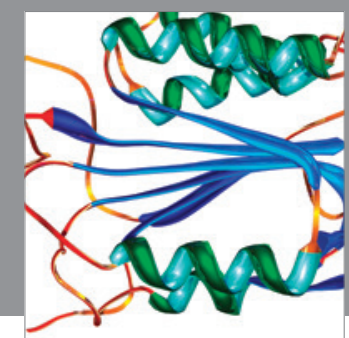

Disease Markers
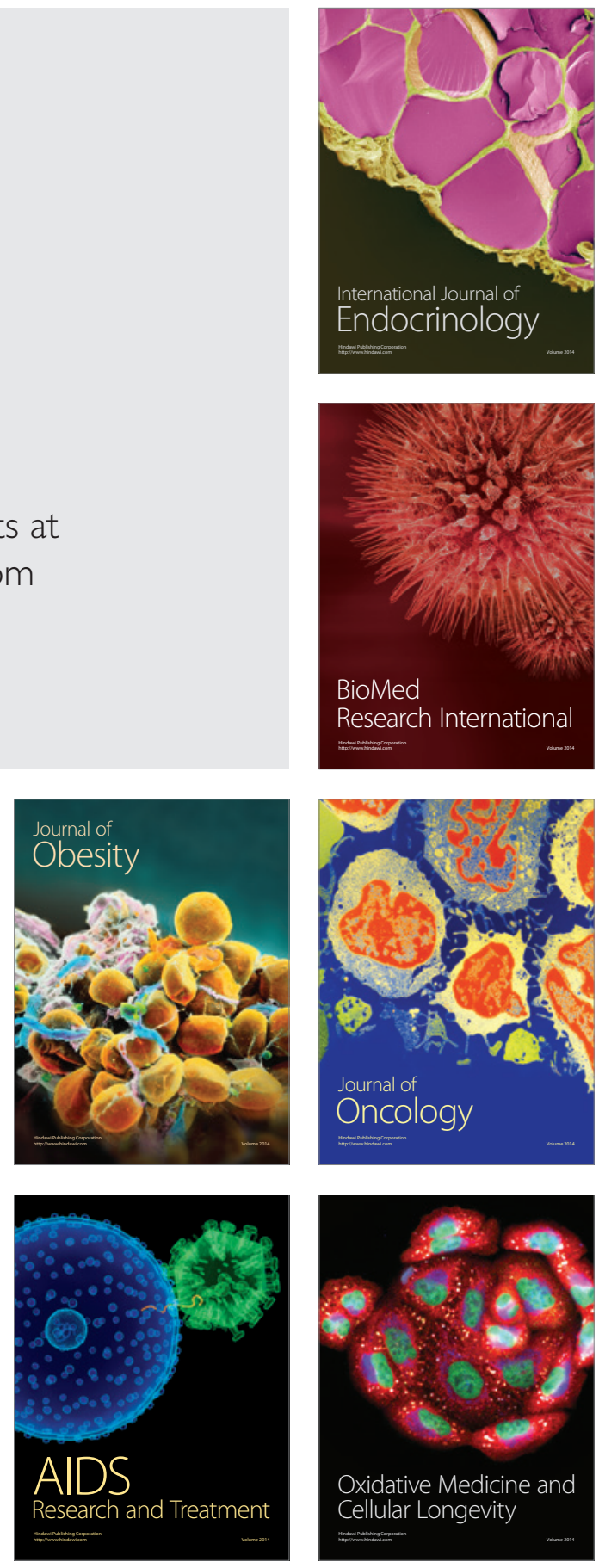